Shivanthan Shanthikumar ORCID iD: 0000-0001-6000-3180

\title{
Bronchoalveolar Lavage in Children: Still the Gold Standard
}

Shivanthan Shanthikumar, MBBS ${ }^{1,2,3}$ and Sarath C Ranganathan, PhD ${ }^{1,2,3}$

1. Respiratory and Sleep Medicine, Royal Children's Hospital, Melbourne, Australia

2. Respiratory, Murdoch Children's Research Institute, Melbourne, Australia

3. Department of Paediatrics, University of Melbourne, Melbourne, Australia

Corresponding Author; Dr Shivanthan Shanthikumar; Respiratory Medicine, Royal Children's Hospital, 50 Flemington Road, Parkville, VIC, 3052, Australia; shivanthan.shanthikumar@rch.org.au

Acknowledgements; The authors have no conflicts of interest to declare

\section{Keywords;}

Paediatrics

Bronchoalveolar Lavage

Cystic Fibrosis

Protracted Bacterial Bronchitis

Dear Editor,

We read with great interest the recent article by Craven et al, entitled "High levels of inherent variability in microbiological assessment of bronchoalveolar lavage samples from children with persistent bacterial bronchitis and healthy controls. ${ }^{1}$ In a small study of 18 children, funded by GlaxoSmithKline, the authors demonstrate variability in the results of bronchoalveolar lavage (BAL) collected from controls and children with protracted bacterial bronchitis (PBB). Specifically, they show that when the BAL

This is the author manuscript accepted for publication and undergone full peer review but has not been through the copyediting, typesetting, pagination and proofreading process, which may lead to differences between this version and the Version of Record. Please cite this article as doi: 10.1002/ppul.25136.

This article is protected by copyright. All rights reserved. 
was divided and sent to two laboratories the results were discordant in terms of both the organisms isolated and their relative abundance. From these data the authors draw conclusions which include questioning "assumptions about this procedure being the gold standard." Whilst these data are of interest, there are significant limitations to their value especially when considering existing literature.

One of the key findings of the study is the discordant results between laboratories. A lack of detail regarding the methods used at each site is a major limitation. It is recognised that laboratory processes can affect the yield of samples collected from patients with chronic airway infection, and the need for a consistent approach has led to disease specific consensus guidelines on this topic. ${ }^{2}$ The discordant results seen in the study could result from different laboratory handling of specimens, and hence the findings of this study could purely be explained by a difference in practice between two centres, not least of which was the transport of samples to the second laboratory in STGG. Molecular studies have identified that even media considered sterile can contain numerous organisms albeit in low densities. ${ }^{3}$ We note that it was laboratory 2 where additional bacteria were cultured from the BAL.

Hare et al analysed BAL samples from 655 children collected and analysed at two different sites compared with 18 samples in the study of Craven et al. ${ }^{4}$ They compared bacterial pathogen load (control, negative, $10^{2}$ colony forming units per $\mathrm{ml}$ (CFU/ml), $10^{3} \mathrm{CFU} / \mathrm{ml}, 10^{4} \mathrm{CFU} / \mathrm{ml}, 10^{5} \mathrm{CFU} / \mathrm{ml}$ ) and inflammatory markers to determine an appropriate definition for infection. They found that a bacterial pathogen load of $\geq 10^{4} \mathrm{CFU} / \mathrm{ml}$ was associated with increased markers of inflammation and hence an appropriate threshold for defining infection. This was in keeping with previous studies. ${ }^{4}$ Whilst the authors contend the current paper does not support the use of $\geq 10^{4} \mathrm{CFU} / \mathrm{ml}$, given it only includes 13 children with PBB an explanation of the findings of Hare et $a$ in their considerably larger study and other studies needs explanation.

Another key finding of the study was the limited correlation between semiquantitative and quantitative methods of measuring bacterial pathogen load. Whilst there has not been direct comparison of different methods of determining 
bacterial pathogen load in PBB and other paediatric suppurative disorders, a large amount of data speaks to the validity of using a semiquantitative or qualitative approach. For instance, the previously discussed Hare et al study utilised a semiquantitative approach, and was able to clearly identify a threshold for lower airway infection that was associated with inflammation. In addition, the qualitative approach used by AREST CF (the long running study of CF patients cited in the article) to define infection is supported by the fact that this definition is associated with important clinical outcomes. For example, in a recent AREST-CF study analysing 1161 BAL from 265 children with CF, the presence of early life infection using the AREST-CF definition, was associated with future risk of structural lung disease severity. ${ }^{5}$

Further, we have used molecular studies to assess the microbiome in CF and shown considerable agreement between pathogen-dominated microbiota and routine laboratory bacterial culture even though these samples were assessed by two different techniques, in two laboratories in different continents and analysed two decades apart in time. ${ }^{6}$

Despite the data that contradicts the findings of their study, and while not discussed by the authors themselves, we do contend that use of both quantitative and semiquantitative microbiologic cultures are likely problematic given that bacterial density is influenced by the dilution from the $0.9 \%$ saline used to lavage the target lobe. Dilution further depends on the volume of return retrieved on suctioning. The consensus has been that standardising for this dilution is not required but data supporting this are few.

In summary, there are significant issues that limit the value of the key findings of the study by Craven et al. A large amount of published data in PBB and cystic fibrosis support the use of BAL as a biological specimen associated with important clinical outcomes. These studies have been conducted in multiple centres, over many years, and included many children. While the findings of Craven et al highlight there can be inconsistencies in results, this potentially speaks to the methods used by the laboratories involved in handing the small number of samples. When these findings

This article is protected by copyright. All rights reserved. 
are compared to the large amount of evidence already generated, they should prompt evaluation of local practices and not just a reconsideration of whether BAL is the gold standard method of sampling the lower airway of children with suppurative lung disease. While we believe that BAL remains the gold standard for the detection of lower respiratory infection we do not believe it is a perfect test and its use and many limitations need to be considered and minimised.

Therefore, we agree with the authors that interpretation of microbial culture results utilizing BAL samples can be challenging. However, we disagree that assumptions about this procedure being the "gold standard" fail to take into account its many limitations as despite these BAL remains the best test to detect endobronchial infection that is associated with lower respiratory inflammation especially in CF.

\section{References}

1. Craven V, Hausdorff WP, Everard ML. High levels of inherent variability in microbiological assessment of bronchoalveolar lavage samples from children with persistent bacterial bronchitis and healthy controls. Pediatric pulmonology 2020.

2. Denton M, Doherty C, Foweraker J, et al. Laboratory standards for processing microbiological samples from people with cystic fibrosis. Cystic Fibrosis Trust; Report of the UK Cystic Fibrosis Trust Microbiology Laboratory Standards Working Group: Kent, UK 2010.

3. Salter SJ, Cox MJ, Turek EM, et al. Reagent and laboratory contamination can critically impact sequence-based microbiome analyses. BMC biology 2014; 12: 87.

4. Hare KM, Pizzutto SJ, Chang AB, et al. Defining lower airway bacterial infection in children with chronic endobronchial disorders. Pediatric pulmonology 2018; 53(2): 224-32.

5. Rosenow T, Mok LC, Turkovic L, et al. The cumulative effect of inflammation and infection on structural lung disease in early cystic fibrosis. The European respiratory journal 2019; 54(1).

This article is protected by copyright. All rights reserved. 
6. Frayman KB, Armstrong DS, Carzino R, et al. The lower airway microbiota in early cystic fibrosis lung disease: a longitudinal analysis. Thorax 2017; 72(12): 110412.

This article is protected by copyright. All rights reserved. 


\section{University Library}

\section{- M M I N E R VA A gateway to Melbourne's research publications}

Minerva Access is the Institutional Repository of The University of Melbourne

Author/s:

Shanthikumar, S;Ranganathan, SC

Title:

Bronchoalveolar lavage in children: Still the gold standard

Date:

2020-11-03

Citation:

Shanthikumar, S. \& Ranganathan, S. C. (2020). Bronchoalveolar lavage in children: Still the gold standard. PEDIATRIC PULMONOLOGY, 56 (2), pp.325-326. https://doi.org/10.1002/ ppul.25136.

Persistent Link:

http://hdl.handle.net/11343/276572 